\title{
Toxicological Effects of Sudan III Azo Dye in Palm Oil on Liver Enzyme and Non Enzyme Markers of Albino Rat
}

\author{
Nwachoko Ndidi ${ }^{1, ~ *}$, Odinga Tamuno-boma ${ }^{1}$, Akuru Udiomine Brantley ${ }^{1}$, \\ Ibanibo Tamunomiebam Emmanuel ${ }^{2}$ \\ ${ }^{1}$ Department of Biochemistry, Rivers State University, Nkpolu-Oroworukwo, Port Harcourt, Rivers State, Nigeria \\ ${ }^{2}$ Department of Chemistry (Biochemistry Option), Rivers State University, Nkpolu-Oroworukwo, Port Harcourt, Rivers State, Nigeria
}

Email address:

blessedconfidence@yahoo.com(Nwachoko N.),Bomaodinga@gmail.com(Odinga T.),minebrantley@gmail.com(Akuru U.B.), ibanibotamunomiebam@gmail.com(Ibanibo T.E.)

${ }^{*}$ Corresponding author

\section{To cite this article:}

Nwachoko Ndidi, Odinga Tamuno-boma, Akuru Udiomine Brantley, Ibanibo Tamunomiebam Emmanuel. Toxicological Effects of Sudan III Azo Dye in Palm Oil on Liver Enzyme and Non Enzyme Markers of Albino Rat. International Journal of Nutrition and Food Sciences. Vol. 9, No. 4, 2020, pp. 104-111. doi: 10.11648/j.ijnfs.20200904.12

Received: June 16, 2020; Accepted: July 1, 2020; Published: July 30, 2020

\begin{abstract}
The economic and nutritional value of palm oil has made its utilization to be on the increase especially in Nigeria, thereby making it expensive, hence the temptation to adulterate it by bulk buyers with the wrong assertion of retaining the quality. This study was therefore undertaken to evaluate the effect of adulterated palm oil on the activity of liver enzymes and non-liver enzymes markers of albino rats. Twenty rats divided into five groups of four rats each were used for this investigation for fourteen (14) days. At the end of the experiment, the animals were sacrificed, blood samples were collected for biochemical analysis. Biochemical indices of liver enzymes makers and non-liver markers were determined. Liver enzymes ALP and ALT concentrations showed significant increase $(\mathrm{p}<0.05)$ when compared with group 1 and 2 , also non-liver markers albumin, conjugated and total bilirubin showed significant increase $(\mathrm{p}<0.05)$ when compared to group 1 and 2 . Histopathological examination showed mild inflammation of the liver for group 3, while histological features for groups (4 \& 5) administered with higher dosage showed intense periportal and intraparenchymal inflammations. A compromise in liver function in rats administered with adulterated palm oil was observed.
\end{abstract}

Keywords: Sudan III Dye, Palm Oil, Bilirubin, Albumin, Liver Function Biomarkers

\section{Introduction}

Colorants (dyes and pigments) are important industrial chemicals. According to the technological nomenclature, pigments are colorants which are insoluble in the medium to which they are added, whereas dyes are soluble in the medium [1]. Sudan dyes are the azo dyes which when eaten can be split into amines that are carcinogenic [1]. Sudan dyes are in the family of azo-dyes which are industrial dye used in the manufacture of plastics [2]. Azo colorants are the most important class of synthetic dyes and pigments, representing $60-80 \%$ of all organic colorants [2]. The use of Sudan dyes in food is to enhance and maintain its colour constitutes which has been a major public health concern [3]. These dyes include Sudan I, II, III, and IV which are weak acids classified as category 3 carcinogens due to the induction of some types of cancer related to bladder and liver in animals [4]. Sudan dyes I, II, III, IV, and their degradation products are considered harmful to human health due to their teratogenicity, genotoxicity, and carcinogenicity [4].

Azo dyes comprise one or more nitrogen-nitrogen double bonds which are referred to as azo groups [3]. Azo dyes under reductive conditions could be cleaved [5]. The azo group when cleaved results in aromatic amines. A proportion of these amines have been classified as being potentially carcinogenic to humans. Sudan dyes have genotoxic effects and that ingestion of food products contaminated with Sudan I, II, III, and IV and Para Red could lead to exposure in the human gastrointestinal tract [5]. Although azo dyes can be 
reduced by the mammalian liver to form aromatic amines, it has been suggested that intestinal micro flora could be primarily responsible for the in vivo reduction of azo dyes [3]. The potential for mutagenicity of azo dyes depends on the ability of the molecule to produce aromatic amines which are active [3]. This action is influenced by the structural relationship, which results in the breakage of the azo linkage leading to oxidation of the primary aromatic amine which has been liberated [1]. The Liver and gastrointestinal tract are major sites where the breaking of the azo linkage can occur [2].

The liver is the largest gland of the body enclosed within the right lower rib cage beneath the diaphragm [6]. It is almost completely covered by visceral peritoneum as well as completely covered by a dense irregular connective tissue layer that lies deep to the peritoneum [7]. Liver is divided into two principal lobes, a large right lobe, and a smaller left lobe separated by falciform ligament [6]. The right lobe is considered by many anatomists to include an inferior quadrate lobe and a posterior quadrate lobe and the liver has five surfaces as Anterior, posterior, superior, inferior, and right [7]. The liver has several functions. It plays a role in digestion (sugar and fat metabolism) and the body's immune defense. It processes almost everything a person eats, breathes, or absorbs through the skin [8]. About $90 \%$ of the body's nutrients pass through the liver from the intestines and converts food into energy, stores nutrients, and produces blood proteins [9]. The liver also acts as a filter to remove harmful substances from the blood. In the developing fetus, blood cells are produced in the liver [10].

The liver regulates the storage of fats by converting amino acids from digested food into fatty acids such as triglycerides; when the body does not have enough sugar, the liver converts fatty acids into ketones, which can be used for fuel [11]. Liver enzymes called aminotransferases or transaminases (ALT and AST) break down amino acids from digested food and rebuild them into new proteins needed by the body [6]. When liver cells are inflamed or damaged, these enzymes can leak out and build up to high levels in the blood; these enzymes can be measured using a simple blood test [6]. Assays for alanine aminotransferase (ALT), aspartate aminotransferase (AST) and alkaline phosphatase (ALP) are the most common laboratory tests used for the detection of liver diseases/integrity [12].

The liver aminotransferases (ALT and AST) are found abundantly within hepatocytes and they catalyze the transfer of amino groups to generate products in gluconeogenesis and amino acid metabolism [13]. Alkaline phosphatase is a hydrolase enzyme that catalyzes the hydrolysis of inorganic pyrophosphate, which is a vascular calcification inhibitor [12]. Serum levels of ALP are commonly used in clinical practice as a marker of liver or bone disease [13].

There have been important advances in the understanding of the physiological functions of these liver enzymes and several epidemiological associations have been reported [13]. Several prospective epidemiological associations have been demonstrated between these markers of liver dysfunction and risk of type 2 diabetes mellitus, cardiovascular disease (CVD) or mortality from vascular and nonvascular causes [6].

The fruits of the oil palm Elaeisguineensis produces Palm oil which is an edible oil [14]. The cheapest and commonly used oil in Nigeria is Palm oil from the fruits of Elaeisguineensis [14]. They are known to be highly rich in fats and oil that serve as an important source of fuel for the body's metabolic process [15]. Fats and oils play important roles in the body, apart from imparting desirable taste and flavors to food [16]. In addition, fats and oils are sources of essential fatty acids and carriers of fat soluble vitamins [16]. Dietary fats and oils are mainly composed of triacylglycerol and cholesterol. Fats and oils which contain more unsaturated fatty acids are particularly susceptible to oxidation, intake of food containing oxidized lipid increased the concentration of secondary peroxidation products in the liver [16]. However, fats and oils which contain high levels of saturated fatty acids increase blood cholesterol levels and hence the risk of cardiovascular disease $[15,17]$. Thermally oxidized palm oil is different from the fresh palm oil because of the presence of free radicals released as a result of heating [17].

The fresh palm oil contains about 50\% saturated and 50\% unsaturated fatty acids, it also contains vitamins $\mathrm{A}, \mathrm{E}$ and carotenes which are antioxidants [18].

The fruit produces two distinct types of oil: orange-red crude palm oil which is extracted from the mesocarp and brownish yellow crude palm kernel oil extracted from the seeds (kernel) [18]. The former consists of mainly palmitic and oleic acids and the latter is mainly lauric acid. Both oils are important in the world trade. Crude palm oil (CPO) is the richest natural source of carotenoids and tocotrienols [19]. The carotenoids (500-700 ppm) are responsible for the characteristic deep orange-red color [19]. In recent years, there has been rising production (supply) and consumption (demand) of palm oil in Nigeria, with demand growing faster than the supply [18]. This widening gap between demand and production has also been accompanied by increasing reports (from the media) of adulteration [20]. Adulteration of fats and oils is an old problem and has been the subject of many studies [21].

There is a wide spread speculation in Nigeria that crude palm oil is being adulterated [21]. The adulteration is believed to be practiced by primary bulk buyers with the knowledge of producers in order to enhance the quality of $\mathrm{CPO}$, for the sole purpose of profit maximization [21]. Unfortunately, the adulteration practice is normally done without considering its possible effect on the quality of palm oil and the health of consumers [22]. One major problem associated with the use of adulterants is that these compounds have not undergone stringent studies and the level of threat they may pose to human health when consumed is also not well established [22]. Crude palm oil, adulteration could lead to loss of quality and nutritive properties, loss of organoleptic attributes and overall degradation of the oil [22]. 


\section{Materials and Methods}

\subsection{Sample/ Animal Collection}

The pure sample (SUDAN III) was collected at a local store at the mile 3 market in Port Harcourt, Rivers State, Nigeria.

The animals (albino rats) were collected from the animal house of the Department of Biochemistry, University of Port Harcourt.

\subsection{Animal Grouping/Administration of the Sample}

The albino rats were grouped into five (5) $(1,2,3,4$ and 5) of four (4) rats in each group. Animals in group 1 served as control, group 2 animals were given unadulterated sample, while groups 3, 4 and 5 were administered with adulterated sample at different concentration $(0.1,0.2$ and 0.5$) \mathrm{g} / 20 \mathrm{ml}$ of palm oil respectively. Each of the animals was given $1 \mathrm{ml}$ of the sample after seven (7) days of acclimatization for fourteen (14) days.

\subsection{Sample Collection}

The rats were sacrificed; their blood and liver were collected and taken to the laboratory for analysis.

\subsection{Histological Examination of Liver Organ}

The liver of both the control and experimental groups were removed immediately after sacrifice and fixed in formalin solution for $24 \mathrm{hrs}$ and then dehydrated with ascending grade of alcohol ( $80 \%$ ethanol), cleared in xylene and embedded in paraffin wax. Thin sections of 7 microns thick were sectioned using a rotatory microtome. The sections were then deparaffinized and stained using the routine with haematoxylin and eosin ( $\mathrm{H} \& \mathrm{E})$. The sections were then examined under bright field light microscopy, and Photomicrographs of the desired results were obtained using digital research photographic microscope in the livelystone laboratory.

\section{Results}

Table 1. TOXICOLOGICAL EFFECT OF SUDAN III IN PALM OIL ON LIVER ENZYME MAKERS.

\begin{tabular}{|c|c|c|c|c|}
\hline Group & Treatment & $\operatorname{AST}(\mu / \mathbf{l})$ & $\operatorname{ALT}(\mu / \mathbf{l})$ & $\operatorname{ALP}(\mu / \mathbf{l})$ \\
\hline 1 & CONTROL & $42.25 \pm 0.85^{\text {bfhJ }}$ & $79.75 \pm 0.63^{\text {afhj }}$ & $23.25 \pm 0.48^{\mathrm{bfh}}$ \\
\hline 2 & Non adulterated & $45.03 \pm 0.23^{* \text { afhj }}$ & $83.37 \pm 0.45^{* a c h j}$ & $25.75 \pm 0.49^{* \text { afhj }}$ \\
\hline 3 & $0.1 \mathrm{~g} / 20 \mathrm{ml}$ & $49 \pm 0.91^{* \text { behj }}$ & $85.62 \pm 0.48^{* a c j}$ & $31.5 \pm 0.64^{* \text { bchjf }}$ \\
\hline 4 & $0.2 \mathrm{~g} / 20 \mathrm{ml}$ & $56.75 \pm 0.85^{* \mathrm{bfg} j}$ & $89.67 \pm 2.67^{* \mathrm{bcgj}}$ & $37.25 \pm 0.63^{* \text { bfyj }}$ \\
\hline 5 & $0.5 \mathrm{~g} / 20 \mathrm{ml}$ & $70.00 \pm 0.81^{* \mathrm{bfhj}}$ & $112.75 \pm 1.11^{* b f h i}$ & $45 \pm 0.91^{* b f h i}$ \\
\hline
\end{tabular}

$\mathrm{KEY}: \mathrm{AST}=$ aspartate aminotransferase, $\mathrm{ALT}=$ alanine aminotransferase, $\mathrm{ALP}=$ alkaline phosphatase,

Values are expressed as mean \pm standard error.

Values in each column with superscript $\left(^{*}\right)$ differ significantly when comparing control with groups $1,2,3$ and 4. Values with different superscript $(a, b)$ differ significantly when comparing group 1 with control and group 2, 3, and 4 . Values with different superscript (c, f) differ significantly when comparing group 2 with control and group (1, 3 and 4).
Values with different superscript $(g, h)$ differ significantly when comparing group 3 with control and group $(1,2$, and 4). Values with different superscript $(i, j)$ differ significantly when comparing group 4 with control and group (1, 2, and 3) at $\mathrm{p}<0.05$.

Table 2. TOXICOLOGICAL EFFECT OF SUDAN III IN PALM OIL ON NON LIVER MAKERS.

\begin{tabular}{|c|c|c|c|c|c|}
\hline Group & Treatment & $\mathbf{T P}(\mu / \mathrm{l})$ & $\mathrm{CB}(\mu / \mathrm{l})$ & $\mathrm{TB}(\mu / \mathrm{l})$ & $\operatorname{ALB}(\mu / \mathbf{l})$ \\
\hline 1 & CONTROL & $66.75 \pm 0.25^{\text {afhj }}$ & $6.9 \pm 0.12^{\text {bfhj }}$ & $14.75 \pm 0.25^{\text {afhj }}$ & $34.75 \pm 0.25^{\text {affij }}$ \\
\hline 2 & Non adulterated & $67.75 \pm 0.63^{* \text { afhj }}$ & $7.9 \pm 0.23^{* \text { afhj }}$ & $16.25 \pm 0.25^{* a c h j}$ & $36.0 \pm 0.41^{* \text { achj }}$ \\
\hline 3 & $0.1 \mathrm{~g} / 20 \mathrm{ml}$ & $72.5 \pm 0.64^{* \text { bchj }}$ & $8.9 \pm 0.22^{* \text { bcfhj }}$ & $18 \pm 0.58^{* \text { acgj }}$ & $37.0 \pm 0.41^{\text {*achj }}$ \\
\hline 4 & $0.2 \mathrm{~g} / 20 \mathrm{ml}$ & $76.5 \pm 0.64^{* \mathrm{bggj}}$ & $10.37 \pm 0.29^{* \mathrm{bfgj}}$ & $19.5 \pm 0.50^{*}$ bcgj & $39 \pm 0.41^{*} \mathrm{bggj}$ \\
\hline 5 & $0.5 \mathrm{~g} / 20 \mathrm{ml}$ & $83.25 \pm 1.25^{* \text { bfhj }}$ & $12.1 \pm 0.19^{* \text { bfhi }}$ & $23.5 \pm 1.32^{* \text { bfhi }}$ & $44 \pm 0.58^{* \text { bfhj }}$ \\
\hline
\end{tabular}

$\mathrm{KEY}$ : $\mathrm{TP}=$ total protein, $\mathrm{CB}=$ conjugated bilirubin, $\mathrm{TB}=$ total bilirubin, $\mathrm{ALB}=$ albumin.

Values are expressed as mean \pm standard error.

Values in each column with superscript $\left(^{*}\right)$ differ significantly when comparing control with groups $1,2,3$ and 4. Values with different superscript $(a, b)$ differ significantly when comparing group 1 with control and group 2, 3, and 4 . Values with different superscript $(\mathrm{c}, \mathrm{f})$ differ significantly when comparing group 2 with control and group (1, 3 and 4).
Values with different superscript $(\mathrm{g}, \mathrm{h})$ differ significantly when comparing group 3 with control and group (1, 2, and 4). Values with different superscript $(i, j)$ differ significantly when comparing group 4 with control and group $(1,2$, and 3$)$ at $\mathrm{p}<0.05$.

Result of Histological Examination of The Liver (X 100) 

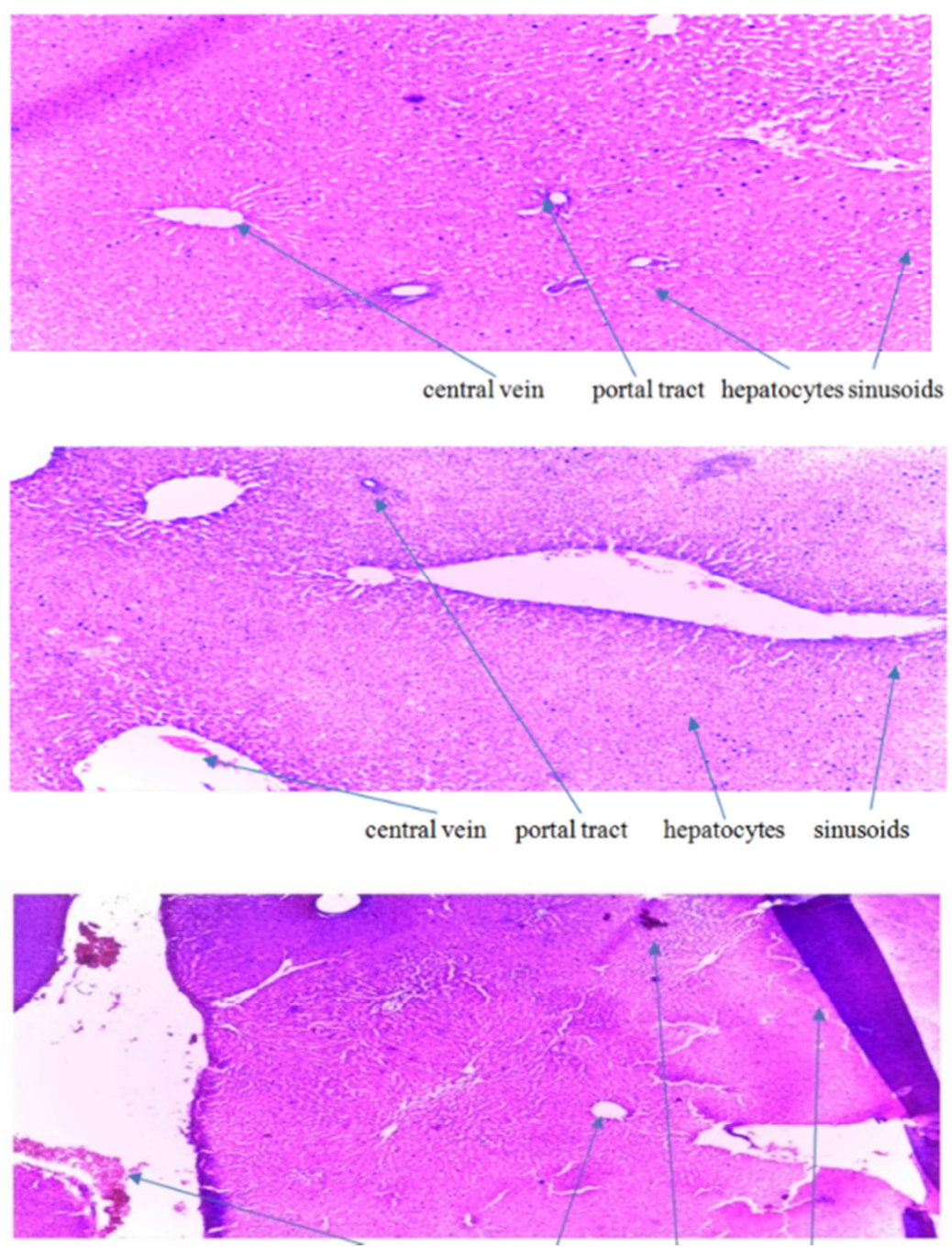

Figure 1. Photomicrographs of the liver of the animals in group 1. (Control). The slides showed normal histological features of the liver.
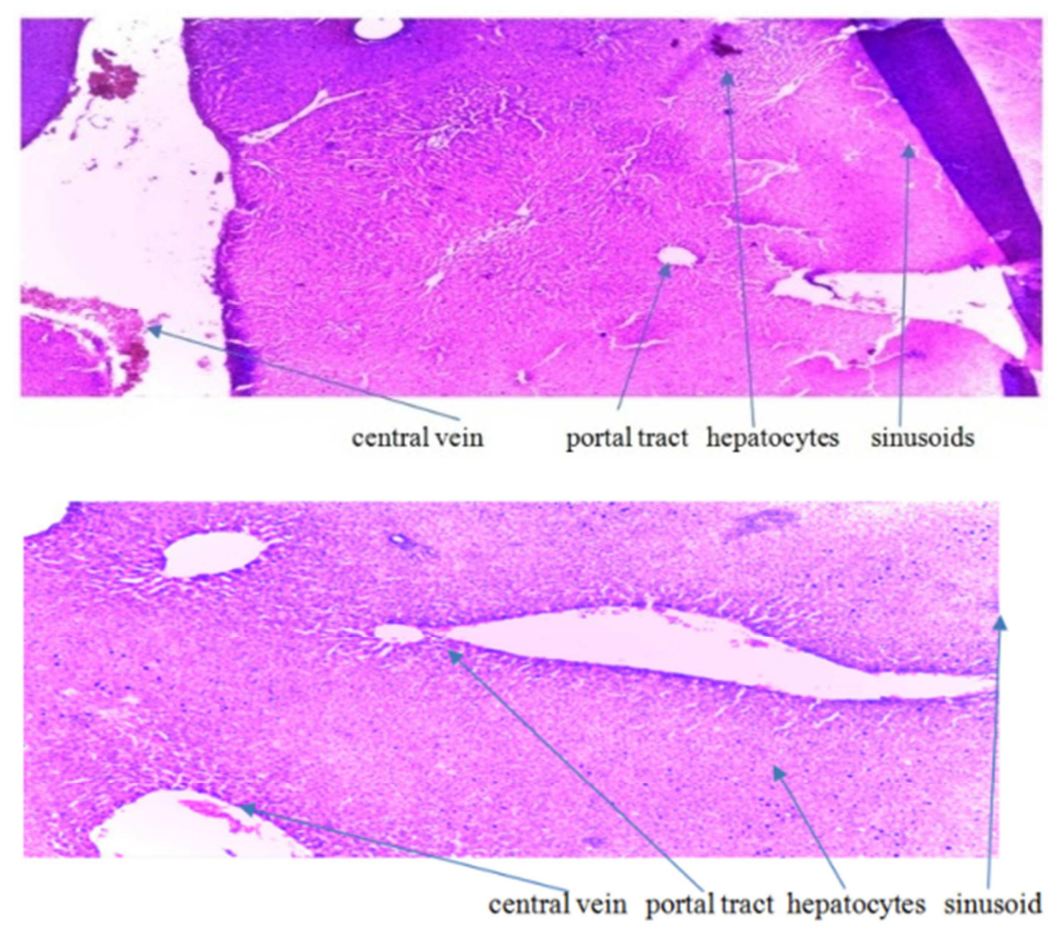


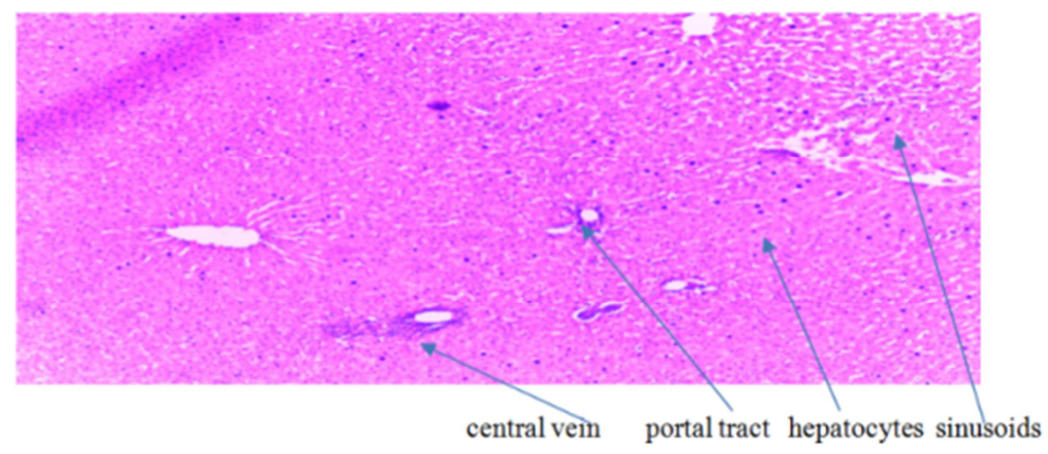

Figure 2. Photomicrographs of the liver of the animals in group 2 administered with unadulterated palm oil. The slides showed normal histological features of the liver.
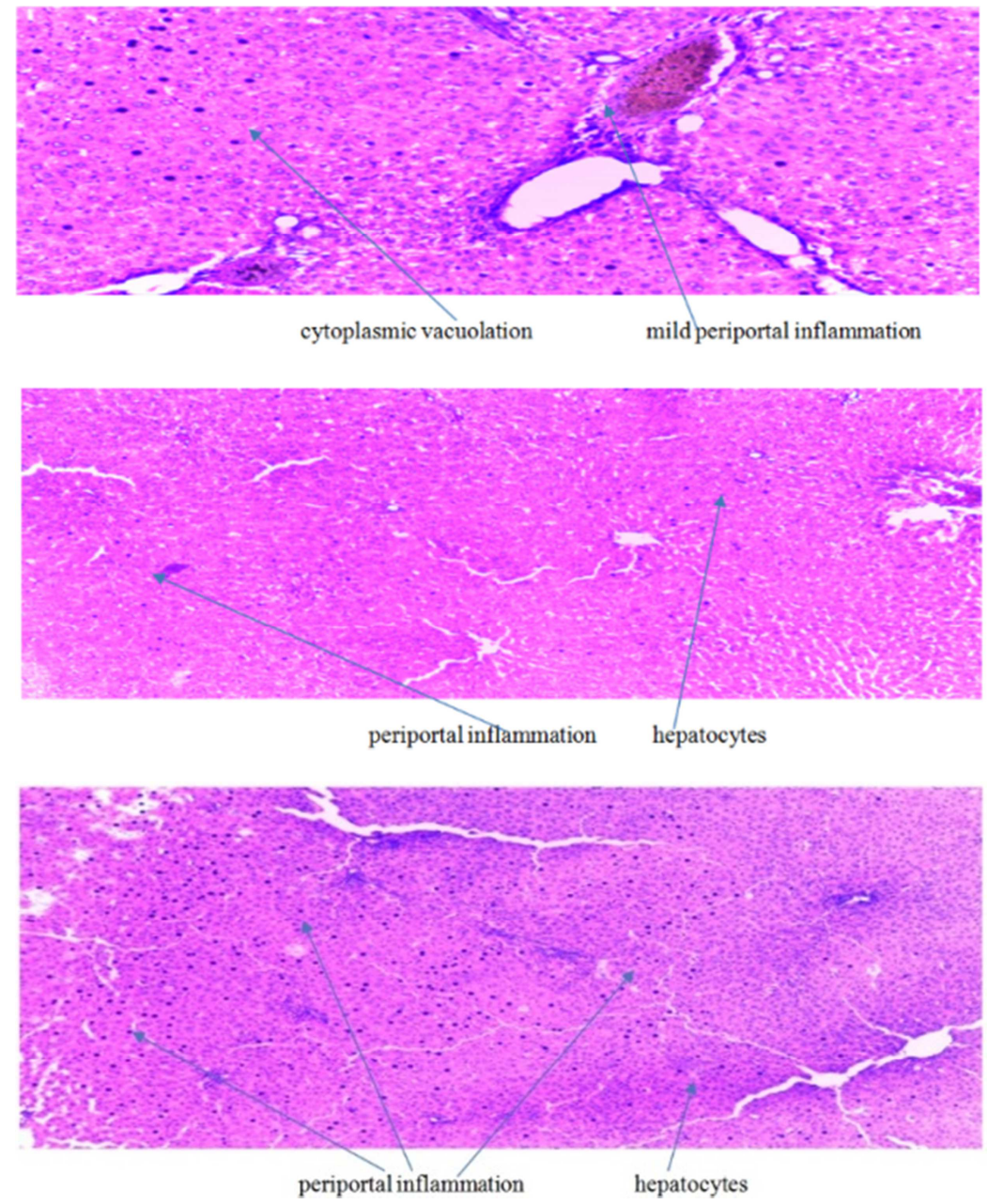

Figure 3. Photomicrographs of the liver of the animals in group 3 administered with $0.1 \mathrm{~g} / 20 \mathrm{ml}$ of adulterated palm oil. Slides showed slight abnormal histological features.

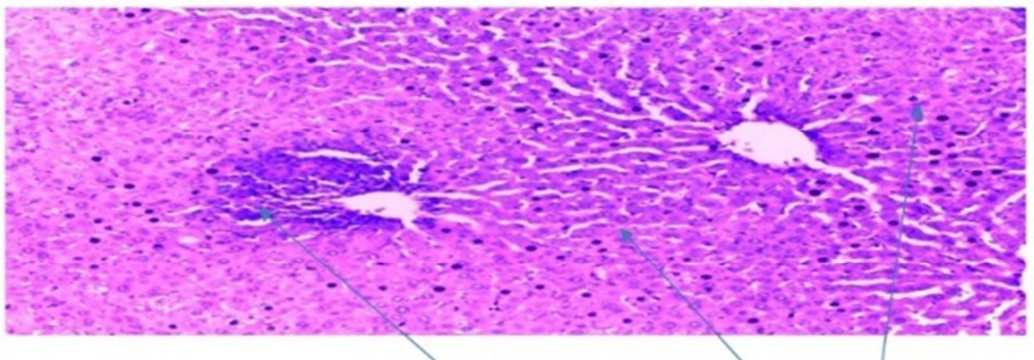

periportal inflammation dilated sinusoids hepatocytes 


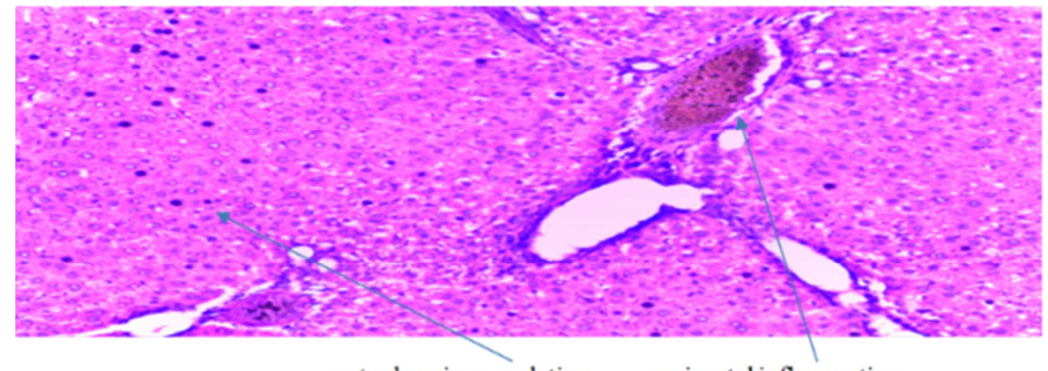

cytoplasmic vacuolation periportal inflammation

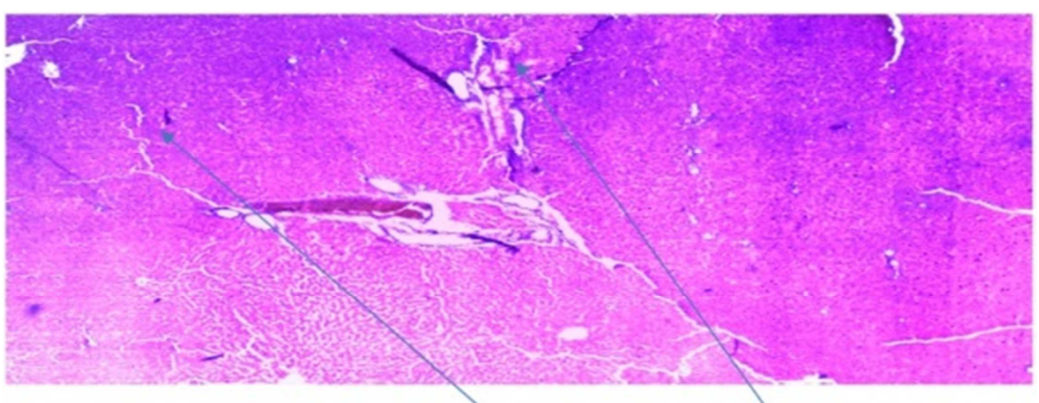

cytoplasmic vacuolation periportalinflammation

Figure 4. Photomicrographs of the liver of the animals in group 4 administered with $0.2 \mathrm{~g} / 20 \mathrm{ml}$ of adulterated palm oil. The slides showed intense periportal and intraparenchymal inflammations

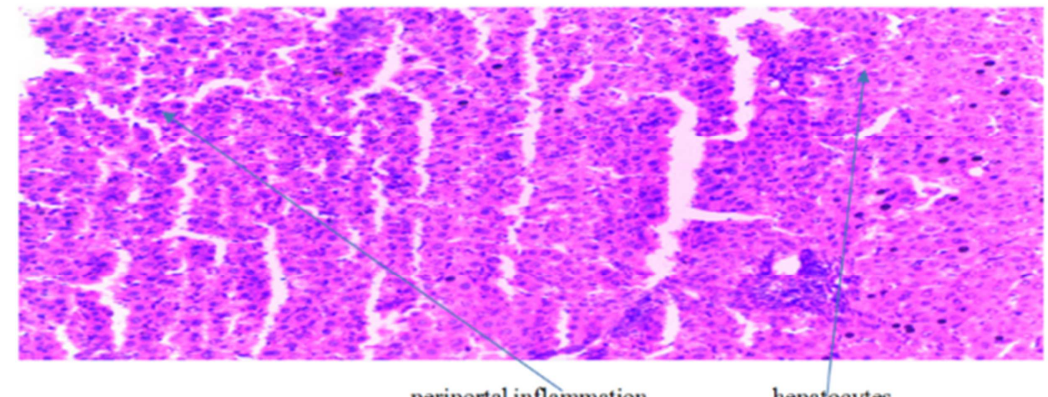

periportal inflammation

hepatocytes
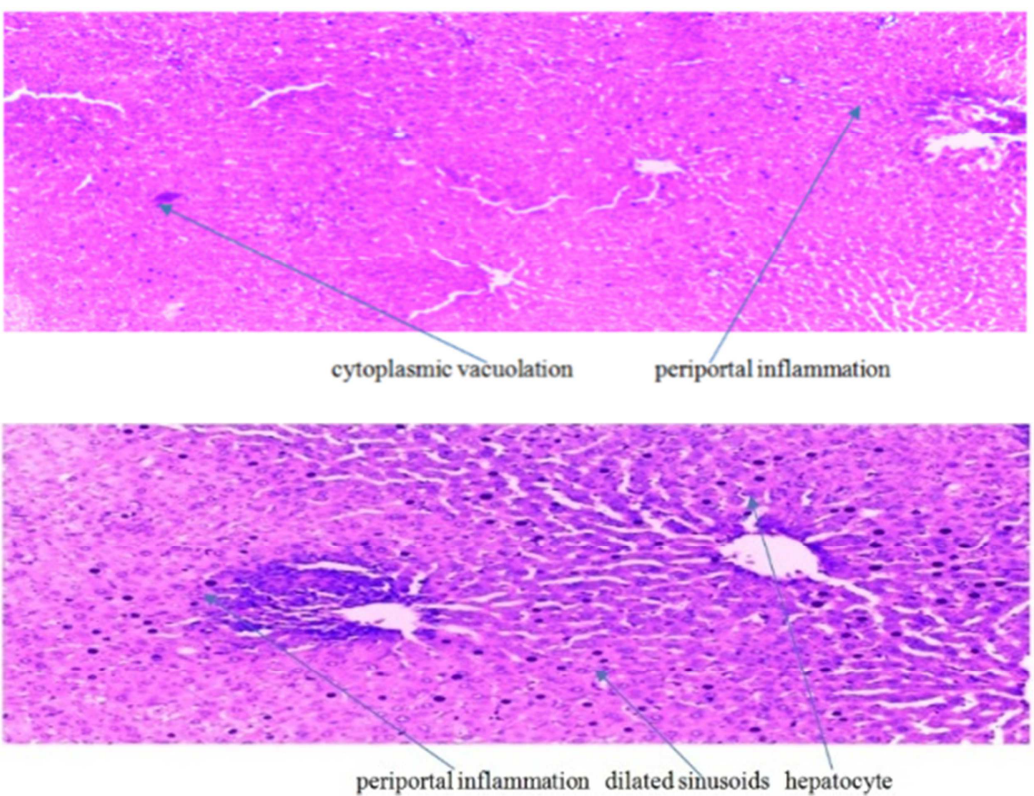

Figure 5. Photomicrographs of the liver of the animals in group 5 administered with $0.5 \mathrm{~g} / 20 \mathrm{ml}$ of adulterated palm oil. Slides showed Intense periportal and intraparenchymal inflammations 


\section{Discussion}

One major problem associated with the use of adulterants is that these compounds have not undergone stringent studies and the level of threat they may pose to human health when consumed is not well established [22]. Adulteration of crude palm oil could lead to loss of quality and nutritive properties, loss of organoleptic attributes and overall degradation of the oil [22].

Results of the effect of adulterated palm oil with Sudan III dye on the values of liver enzyme and non-liver markers are shown in Tables 1 and 2. These enzymes (ALT, AST and ALP) are abundantly (found in the hepatocytes and usually low in the blood. When liver cells are inflamed or damaged, these enzymes can leak out and build up to high levels in the blood. Table 1 showed the concentrations of liver makers ALT, AST and ALP. The mean values of these enzymes in groups 3,4 and 5 increased significantly $(\mathrm{p}<0.05)$ when compared with the mean values of group 1 (control) and 2 (unadulterated palm oil). The increment in the mean values of the enzymes in the treated groups increases with increase in the level of adulteration. This result agrees with the report of other studies [23] that noted the level of these liver enzymes are usually raised in acute hepatoxicity due to damage to the liver.

Table 2 showed activities of non-liver makers (albumin, total and conjugated bilirubin). The result showed that the mean values of these non-enzyme markers in groups 3, 4 and 5 increased significantly $(\mathrm{p}<0.05)$ when compared with the mean values of group 1 and 2. A similar study [24] reported that increase or decrease in these parameters after administering a chemical is an indication of the toxic effect of that chemical. Bilirubin accumulates from the breakup of hemoglobin present in red blood cells. During normal function, the liver removes bilirubin from the blood and excretes it through the bile. Increases in total bilirubin and conjugated bilirubin observed, compared with the control rats also indicates a compromise in the normal function of the liver in rats administered $0.1 \mathrm{~g}, 0.2 \mathrm{~g}$, and $0.5 \mathrm{~g}$ dye in $20 \mathrm{ml}$ of palm oil.

The result of the histological examination showed some variations. Figures 1-2, showed normal histological features for group 1 (control) and 2 (unadulterated palm oil), while Figure 3 showed the histological features of liver of animals in groups 3 (the group administered with $0.1 \mathrm{~g}$ ), the slides showed slight abnormal histological features, while Figures 4-5 revealed adverse effect of the dye on the liver with increase in the dosage administered. The Figures showed intense periportal and intraparenchymal inflammations. Sudan III dye has been postulated [25] thatit may not only cause tumours in the liver at a high dose of $800 \mathrm{mg} / \mathrm{kg}$ but could cause inflammation to the liver organ at low dose of $0.2 \mathrm{~g}$ and $0.5 \mathrm{~g}$.

\section{Conclusion}

This study showed that Sudan III dye could cause damage to the liver, thus the increase in the enzymatic activity and other non-enzyme markers compared to control. Therefore the use of adulterated palm oil especially with Sudan III should be discouraged.

\section{References}

[1] Hayenga, I. (2011), Sudan Red Dye Standards, New standards $\&$ deuterated standards for the reliable analysis of these carcinogenic compounds in foodstuffs. Journal of Medical Research, 8 (4): 4-6.

[2] Püntener, A. \& Page, C. (2004). European Ban on Certain Azo Dyes, Quality \&Environment. European Journal, 14 (2): 231458.

[3] Chung, K. T., Fulk, G. E. \& Egan. M. (1998). Reduction of azo dyes by intestinal anaerobes. Applied Environmental Microbial Journal, 3 (5): 55-56.

[4] International Agency for Research on Cancer (IARC) (1997). Overall Evaluations of Carcinogenicity. An Updating of IARC Monograph, 2 (1): 3-4.

[5] An, Y., Jiang, L., Cao, J., Geng, C. \& Zhong, L. (2007). Sudan I induces genotoxic effects and oxidative DNA damage in Hep G2 cells mutant rats. Journal of Molecular Biology, 7 (2): $167-170$.

[6] Naganna, B. (1989) Primary investigation of Plasma proteins. Journal of Biochemistry, 10 (1): 5-6.

[7] Panda, N. C (1989). In: Textbook of Biochemistry \& Human Biology, W. H \& Co., London. 2ndEd. Pp. 52-66.

[8] Moudgil, K. D \& Narang, B. S (1989). The liver \& biliary system. In: Textbook of Biochemistry \& Human Biology, United Kingdom: Evergreen Publishing 2nd ed, Pp. 271-273.

[9] Rodwell, V. W (1996). European study on Catabolism of proteins \& of amino acidnitrogen. European Journal, 4 (2): 58.

[10] Kleinman, L. I \& Lorenz, J. M (1989). Clinical biochemical Analysis \& Correlation. Journal of Biochemistry, 5 (2): 6-7.

[11] Bassir, O. (1991) Handbook of Practical Biochemistry. Ibadan University Press, Ibadan, Nigeria, Pp. 53-54.

[12] Humason, G. L. (1996). Animal Tissue Techniques. Journal of Biochemistry, 11 (3): 57-61.

[13] Edem, D. O. \& Akpanabiatu, M. T. (2006). Effects of palm oil containing diets on enzyme activities of rats. Pakistan Journal of Nutrition, 5 (4): 301-305.

[14] Siew W. L. (2002). In textbook: Palm oil and Vegetables Oils in Food Technology Composition, Properties \&Uses. United Kingdom: Blackwell Publishing. 2nd Ed. Pp. 59-97.

[15] Heber, D., Ashley, J. M., Solares, M. C., Wang, H. J. \& AlfinSlater, R. B. (1992). The effects of palm oil enriched diet on plasma lipids \& lipoproteins in healthy young men. Journal of Nutritional Research, 12 (5): 553-560.

[16] Slater, T. F. (1997). Free Radical Mechanisms in Tissue injury. London Journal, 21: 48-54.

[17] Sundram K., Hayes, K. C. \&Siru, O. H (1995), Both dietary 18:2 \& 16:0 may be Required to improve the serum LDL/HDL cholesterol ratio in normocholesterolemic men. Journal of Nutritional Biochemistry. 6 (1): 51-64. 
[18] Ghafourunissa, K. (1995). Nutritional \& Health implications of palm oil. Journal of Medical Research, 1 (2): 233-234.

[19] Gunstone, F. D. (2005). Evaluation of vegetable Oils on F. Shahidi Bailey's Industrial Oil \&Fat Product. Journal of Chromatography. 3 (2): 9-10.

[20] Aparicio, R. Aparicio-Ruiz, R. (2000). Authentication of vegetable oils by chromatographic methods. Journal of Chromatography, 8 (1): 93-97.

[21] Rossell, J. B., King, B., Downes, M. J. (1998). Detection of adulteration. Journal of Applied Chemical Society, 6 (11): $7-$ 11 .

[22] Imai, C., Watanabe, H., \& Haga, N., (1994). Detection of
Adulteration of Cottonseed Oil by Gas Chromatography. Journal of Chemical Society, 5 (6): 326-330.

[23] Obi, E., Orisakwe, O. E., Asomugha, L. A \&Udemezue, O. O (2004). The hepatotoxic effect of halofantrine in guinea pigs. Indian Journal of Pharmaceutical Sciences, 36 (5): 303-305.

[24] Orisakwe, O. E., Hussaini, D. C. \& Afonne, O. J. (2003). Testicular effects of sub- chronic administration of Hibiscus sabdariffa calyx aqueous extract in rats. Indian Journal of Pharmaceutical Sciences, 18 (3): 295-298.

[25] Kirby, A. H \& Peacock, P. R., (1997). The induction of liver tumours by 4 -aminoazobenzene $\&$ its $\mathrm{N}: \mathrm{N}$-dimethyl derivative in rats on a restricted diet. Journal of Pathological Bacterial, 5 (4): $1-7$ 